\title{
Surfaces
}

\section{AHAB AS CAPITALIST, AHAB AS COMMUNIST: REVISING MOBY-DICK FOR THE COLD WAR}

\section{Geraldine Murphy}

Volume 4, 1994

SUR L'ÉPISTÉMOLOGIE DE LA GUERRE FROIDE

ON COLD WAR EPISTEMOLOGY

URI : https://id.erudit.org/iderudit/1064959ar

DOI : https://doi.org/10.7202/1064959ar

Aller au sommaire du numéro

Éditeur(s)

Les Presses de l’Université de Montréal

ISSN

1188-2492 (imprimé)

1200-5320 (numérique)

Découvrir la revue

Citer cet article

Murphy, G. (1994). AHAB AS CAPITALIST, AHAB AS COMMUNIST: REVISING

MOBY-DICK FOR THE COLD WAR. Surfaces, 4. https://doi.org/10.7202/1064959ar
Résumé de l'article

Contrastant les interprétations qu'offrent F.O. Matthiessen et R.W.B. Lewis de Moby-Dick et des derniers romans de Melville (dans American Renaissance et The American Adam, respectivement) avec la réplique révisionniste de Richard Chase (dans Herman Melville : A Critical Study), l'auteure décrit le discours critique sur Melville comme un tribune importante dans le débat qui a permis aux American Studies, après la Seconde guerre, d'exorciser la vielle gauche et d'élaborer une nouvelle définition du libéralisme.
Copyright (c) Geraldine Murphy, 1994

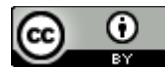

Ce document est protégé par la loi sur le droit d'auteur. L’utilisation des services d'Érudit (y compris la reproduction) est assujettie à sa politique d'utilisation que vous pouvez consulter en ligne.

https://apropos.erudit.org/fr/usagers/politique-dutilisation/ 


\title{
AHAB AS CAPITALIST, AHAB AS COMMUNIST:
}

\author{
REVISING MOBY-DICK FOR THE COLD WAR.
}

\section{Geraldine Murphy}

\begin{abstract}
Contrasting F.O. Matthiessen's and R.W.B. Lewis's interpretations of MobyDick and Melville's later novels (in American Renaissance and The American Adam respectively) with Richard Chase's revisionist rebuttal (in Herman Melville: A Critical Study), the author describes literary discourse on Melville as an important site, in American Studies, to exorcise the old left and redefine liberalism in the postwar period.
\end{abstract}

\section{RÉSUMÉ}

Contrastant les interprétations qu'offrent F.O. Matthiessen et R.W.B. Lewis de Moby-Dick et des derniers romans de Melville (dans American Renaissance et The American Adam, respectivement) avec la réplique révisionniste de Richard Chase (dans Herman Melville: A Critical Study), l'auteure décrit le discours critique sur Melville comme un tribune importante dans le débat qui a permis aux American Studies, après la Seconde guerre, d'exorciser la vielle gauche et d'élaborer une nouvelle définition du libéralisme. 
If postwar critics are to be believed, the word "canonical" barely begins to describe the status of Herman Melville and Moby-Dick in Cold War Americanist circles. In The Power of Blackness, Harry Levin quipped that the exegesis of Moby-Dick had replaced whaling as one of the principal industries of New England. Malcolm Cowley suggested that the outstanding American literary accomplishment since the twenties, eclipsing even the work of Faulkner, Hemingway, and Hart Crane, was "the critical rediscovery and reinterpretation of Melville's Moby-Dick and its promotion, step by step, to the position of national epic" (15). Not to be outdone, Leslie Fiedler claimed an international following for Melville, who "has come to seem not only for America but for the Western world of eminent importance"

("American Literature" 177). The canonization of Melville was not merely a phenomenon of the Cold War, of course, but the culmination of a process of recuperation that had begun in the twenties. Precisely because his stature by the forties and fifties had become indisputable, however, the literary critical discourse on Melville was inscribed by broader political and cultural tensions and thus became an important site for the exorcism of the old left and the redefinition of liberalism in the postwar period.

The growing importance of Melville as a canonical figure coincided with the engagement of literary intellectuals in left-wing politics during the thirties and the subsequent repudiation of the left after the collapse of the Popular Front and the onset of the Cold War. During this time, the two groups of critics who emerged as the most authoritative voices on American literature -- a discipline of strategic cultural importance in the postwar period -- were the liberal-progressive critics associated with American Studies and the New York Intellectuals. Both these groups find their roots in the left, but as "nativists" and "immigrants" -- terms which are empirically imprecise but metaphorically useful -- they were separated by cultural background and thus drew on different traditions of radicalism. In the postwar period, their disagreement over the role of the American Communist Party and the proper stance toward the Soviet Union set them on different courses and confirmed their political and cultural antagonisms. The early American Studies movement, as represented by F. O. Matthiessen (who was active in PopularFront politics and supported Henry Wallace in 1948) and R. W. B. Lewis, remained faithful to the thirties' concept of liberalism while the Partisan Review critics, whose principal spokesman for my purposes is Richard Chase, helped to discredit the old left and establish a centrist, antiCommunist liberalism as the only legitimate alternative to the forces of reaction in postwar American life.[1]

It would be simplistic to assign a progressive Melville to one camp and an anti-Communist Melville to the other, especially since the American Studies critics wrote rather more energetically against the grain of progressive scholarship represented by Brooks and Parrington than within it; nevertheless, both groups did recast Melville in their own political image, as their interpretations of Moby-Dick and Melville's succeeding novels illustrate. Matthiessen and Lewis were not immune to the charms of tragedy, 
irony, and complexity, the political and literary touchstones of anti-Stalinism, yet their celebration of Melville's democratic ethos and faith in the transformative power of Adamic innocence represent a subterranean expression of Popular-Front optimism, kept alive after the collapse of left coalition politics in 1939 and again after the Second World War. For these critics, Billy Budd was the fulfillment of the aesthetic and thematic promise of Moby-Dick. The New York Intellectuals, on the other hand, dismissed this reading of Melville, much as they dismissed the Popular Front itself, as spuriously religious and naive. They constructed a Melville who was the scourge of reform movements in his own day and thus a model for contemporary opponents of "totalitarian" liberalism. Moby-Dick, they argued, was his tragic masterpiece, while Billy Budd was a final, uncharacteristic lapse into sentimentalism and self-indulgence.

The publication of American Renaissance (1941) might logically have provided an occasion for a rapprochement on cultural grounds between the anti-Stalinist modernists and the Popular-Front progressives, for Matthiessen's modulated, Neibuhrian vision, his erudition, his respect for the modernist masters, and his mastery of New Critical interpretive techniques suggest a greater affinity to these contemporaries than to Van Wyck Brooks. Alfred Kazin, the New York Intellectual most receptive to American literature at the time, did review American Renaissance favorably. From the Heart of Europe, however, published in 1948 at the beginning of the Cold War exacerbated the already heightened tensions between the progressive and anti-Stalinist camps.[2] Not only was the tenor of the book anathema to the New York Intellectuals, but Matthiessen also went so far as to criticize explicitly "the bright facile negativism ... [of] those New York writers whose thought has never been nourished by first-hand participation in social action either abroad or at home" (81). This was particularly galling, coming from a Harvard WASP who lived in Louisburg Square and fancied himself a populist. As (symbolically if not actually) working-class Jews who grew up with trade unionism and socialism, and as anti-Stalinists whose authority was based on a thorough knowledge of the dangers of American Communism and "first-hand participation in social action," their credentials as leftists, the New York critics thought, were unimpeachable.

The best known and most virulent attack on From the Heart of Europe was Irving Howe's review in Partisan Review:

Here, once again, is the slightly sad, slightly ridiculous eagerness to sidle up to "the people" ... the pulpy schwärmerei of progressivist festivity ... and the falsely-charged prose style of the fellow-traveler atremble before the glories of the "new world" -- a style that might be called vibrato intime. (1125) 
The striking similarity between this passage and the later characterization of the totalitarian liberal in Howe and Coser's The American Communist Party (1957) suggests that Howe simply lifted one for the other. Matthiessen became for Howe -- as did Alger Hiss for Fiedler and Wallace for Dwight Macdonald -- the prototypical Popular Front intellectual. Aside from the particular provocations of From the Heart of Europe, feelings toward Matthiessen were decidedly cool. In Being Busted (1969) Fiedler recalled a class on modern American poetry he had taken in the late forties at Harvard from "the little gray professor (dead by his own hand only a short while later) making silences into which we rushed, as he curled like a cat in his chair" (47). Even the gentlemanly Trilling could turn feline on the subject of Matthiessen: writing to Chase, who was at Kenyon College at the time, Trilling asked for gossip and confessed, "Matthiessen is one of the objects of my obsessed contemplation: a cheap taste, but indulge it" (7 July 1948). The personal and political antipathy of the New York Intellectuals toward Matthiessen is no secret, but its literary consequences have not been thoroughly explored, and Melville's saga of the white whale is the appropriate place to start.

***

In American Renaissance Matthiessen exalted Melville within the antebellum pantheon to the same degree as did later Cold War critics. The author of Moby-Dick "dominated Matthiessen's imagination of the entire era," and the novel itself, in its "organic display of symbolic richness, verbal power, and acute cultural critique," became the standard by which to evaluate the major works of Melville's contemporaries (Gunn 102; Cain 178). Shakespeare is a presiding spirit who enhances the stature of American literature throughout American Renaissance, but in the section on Melville, Shakespeare is doubly important -- a model for Matthiessen of the "universal" artist as well as a literary influence. Following T. S. Eliot, who attributed Shakespeare's popularity to the various levels within each play that simultaneously appealed to naive and sophisticated members of the audience, Matthiessen saw Moby-Dick as a multilevel drama whose elementary attraction was the adventure of the whale hunt. While Matthiessen did not elevate Melville to the ranks of the empyrean, he did regard him as the closest America had yet come to the universal bard. The parallels he draws between classic and American literature in his efforts at canon formation are hardly idiosyncratic; Hershel Parker notes that by the 1940s, American commentators on Billy Budd regularly and with due solemnity invoked Shakespeare, Sophocles, and Milton (73). However, Matthiessen's characterization of Melville as the American Shakespeare not only legitimated antebellum writers, it also reconciled his own competing commitments to aesthetic excellence and democratic accessibility. 
As for Shakespeare's influence on the composition of Moby-Dick, Matthiessen patiently explicates both its concreteness and presence. The phases of the narrative, he observes, prepare the reader for the key scenes on deck that owe much to Shakespeare's dramatic example, and in his handling of language, Melville graduates from declamatory blank verse to a rich, supple prose inflected by Shakespearian rhetoric. According to Matthiessen, Shakespeare released Melville's creative energies and enabled him as an artist, much as Emerson brought the "simmering" Whitman to a boil -- although what the bard's example engendered was tragedy rather than antebellum confidence. "Shakespeare's conception of tragedy had so grown into the fibre of Melville's thought," says Matthiessen, "that much of his mature work became a recreation of its themes in modern terms" (435). Most importantly, the discrepancy between truth and appearance, which Melville regarded as one of the "central problems of tragedy," was the "common denominator" between the two authors he revered, Shakespeare and Hawthorne (433). - From appearance and reality, Matthiessen shifts almost imperceptibly to the moral "contraries" of good and evil that Hawthorne and Shakespeare explored, providing for Melville the tragic counterpoint to Emersonian optimism.

Matthiessen devotes much of his lengthy discussion of Moby-Dick to Ahab and his obsessive quest for the white whale. In doing so, he is merely following Melville's example, for Ahab, he says, overwhelms earlier themes introduced by Bulkington and by Ishmael and Queequeg. "To a degree even beyond what Melville may have intended, all other personalities, all other human relations became dwarfed before Ahab's purpose" (447). Both hero and villain, Ahab is superior to the "inert mass," yet blasphemous in his megalomania. To Matthiessen, Ahab is a cautionary figure for Melville's age, a nightmare version of Emersonian individualism (447) and a precursor to the robber barons and "empire builders" of the later nineteenth century for whom the metaphysics of evil were not even a vestigial concern (459). His egotism, willfulness, and spiritual isolation from common humanity lead to his own damnation and the destruction of the society represented by the Pequod (656). Though a "Yankee Faust," Ahab fails to struggle against his possession. The reader cannot fully pity him, for "He is not caught out of himself and transfigured by sympathy" (456). Moby-Dick, in Matthiessen's view, was not a formally successful tragedy because Ahab failed to achieve tragic insight. Nevertheless, Melville himself was purged by writing the novel: "He had experienced the meaning of catharsis, even though his protagonist had not" (458).

Matthiessen's preoccupation with tragedy marks him as "counterProgressive," to use Gene Wise's term, and his definition of it is remarkably similar in certain respects to the New York Intellectuals' stoic new liberalism. Tragedy, says Matthiessen, requires mature moral insight, "a profound comprehension of the mixed nature of life." "Tragedy does not pose the situation of a faultless individual (or class) overwhelmed by an evil world, for it is built on the experienced realization that man is radically 
imperfect" (179-80). In embracing Keats's notion of moral complexity and extolling the strenuous demands of maintaining "an inexorable balance" between the moral contraries of good and evil, Matthiessen anticipates Trilling's reliance on "negative capability" as a model for the "opposing self." The New York Intellectuals characterized Popular Front fellow travelers as soft and sentimental, yet at the same time, dangerously doctrinaire in their innocence; although Matthiessen was in their view the Henry Wallace of literary criticism, he was hardly the naif or zealot they imagined, nor did he value in Melville the qualities the anti-Stalinists found so repugnant. Melville's tragic works, according to Matthiessen, were engaged more profoundly with the metaphysical rather than the social (405), and although White Jacket, for example, was a reform novel which exposed the abuse of flogging in the United States Navy, Melville harbored no fond illusions about the victims of injustice: "he did not sentimentalize the sailor ..." Matthiessen asserted:

He wanted it understood that he had no "theoretic love" for him, "no romantic belief in that peculiar noble-heartedness and exaggerated generosity of disposition fictitiously imputed to him in novels." ... [Melville] had learned things which prevented him even more effectually from regarding any class of men as innocent-hearted. Arraigned at the mast and sentenced to an unjust beating, White Jacket had discovered within himself hitherto unsuspected capacities for violence. (403)

Despite its counter-Progressive aspects, however, Matthiessen's notion of tragedy was too optimistic, too Christian, too socially oriented -- and therefore too Popular Frontist -- for the New York Intellectuals to tolerate. Matthiessen emphasized resolution and the "reconciliation of opposites" over the ordeal of maintaining balance between them.[3] Trilling, on the other hand, in The Liberal Imagination (1950), fetishized the drama of a "dialectical" struggle that perpetually deferred synthesis. As Stern and Gunn have observed, tragedy, to Matthiessen, was affirmative and Christian, wresting spiritual victory from earthly defeat; thus Billy Budd was a more fitting example of it than Moby Dick (144-/pp. 11-12/ 45; 119-20). In fact, Matthiessen sees the general development of Melville's career as the "rising counteraction" (Gunn 119) of Billy Budd writ large: a tragic conflict ending in what might be called tragic optimism. According to this scenario, after the achievement of Moby-Dick Melville foundered in a philosophical and formal impasse; epistemological uncertainty overwhelmed moral understanding and thus precluded the possibility of tragedy in the subsequent novels. "[B]ecause the ambiguity of all appearances had become so intense for Melville at the time of The Confidence Man," says Matthiessen, "... there was no real progression to its theme, no possible resolution other than to break off in the middle" (492). Following the "failures" of Pierre, Israel Potter, and The Confidence Man, however, Melville experienced a "recrudescence of his talents" in Billy Budd (499). American Renaissance itself, in fact, unfolds according to the same principles of affirmative tragedy. After the first section, or "book," on Emerson and Thoreau, Matthiessen turns his attention to the tragic writers, Hawthorne 
and Melville, and then concludes his study with Whitman. "At this point," he acknowledges in the introduction to the book on Hawthorne, "the natural sequence would be to consider Whitman, and his development of the organic style," -- but he doesn't want to end on a "tragic" note. The more appropriate way to proceed is "by going from the transcendental affirmation to its counterstatement by the tragic writers, and by then perceiving how Whitman rode through the years undisturbed by such deep and bitter truths as Melville had found" (179).

This optimistic strain in Matthiessen's concept of tragedy derives not only from Christianity but also from his faith in democracy. He insisted upon awareness of the social nature of man as a prerequisite for the tragedian. The successful author of tragedy "must have a coherent grasp of social forces, or, at least, of man as a social being .... For the hero of tragedy is never merely an individual, he is a man in action, in conflict with other individuals in a definite social order" (179). In William E. Cain's succinct formulation,

Tragedy, in complex partnership with democracy, makes us aware that human limitation must check the fervent attachment to ideology and rule at last the soaring spirit of democracy itself. Yet it simultaneously still routes us toward the need for democracy, fraternity, and brotherhood, as when it exhibits for us, in the case of Ahab, the terrible destruction wrought by the isolated and overreaching human will and the horror of a spurned common humanity (151).

Matthiessen attributes the same connections among Christianity, tragedy, and democracy to Melville, whose "fervent belief in democracy was the origin of his sense of tragic loss ..." (442).

Although R. W. B. Lewis, like Matthiessen, was a counter-Progressive, in The American Adam (1955) he would elaborate on the notion that tragedy depends, not so paradoxically, upon faith in God and man. Wryly accusing Emerson of subscribing to "a two-party system in intellectual affairs," Lewis added to his party of Hope and party of Memory a third "party of Irony," whose membership

was characterized by a tragic optimism: by a sense of the tragic collisions to which innocence was liable (something unthinkable among the hopeful), and equally by an awareness of the heightened perception and humanity which suffering made possible (something unthinkable among the nostalgic). (7-8) 
One can only wonder if Wallace's third-party campaign of 1948 and its attendant ironies were on Lewis's mind; by 1955, the ideal of Adamic innocence was more important to a sense of tragedy than to social change. Nevertheless, Gene Wise may be correct in calling Lewis "the most 'Progressive' of all counter-Progressives" (312), for the epilogue of The American Adam, entitled "Adam as Hero in the Age of Containment," turned out to be an extremely discreet critique of the new liberalism and perhaps the New York Intellectuals. The Adamic innocence and optimism of the ninteenth century, says Lewis, is at present likely to be a source of embarrassment rather than inspiration: "the American as Adam has been replaced by the American as Laöcoon;" he says, "the Emersonian figure -'the plain old Adam, the simple genuine self' -- has been frowned quite out of existence" (197). In sacrificing a crucial dialectical tension with idealism, the prevailing mood of disillusionment has degenerated into simplistic despair: "something which began as a valuable corrective to the claims of innocence in America ... has declined into a cult of original sin" (198). Lewis refuses to name names and exibits considerable rhetorical skill avoiding them, but contemporary intellectuals may very well have understood a reference to original sin as an allusion to the neo-Calvinist Reinhold Niebuhr. Similarly, it may not be far off the mark to take the following observation -- "we sometimes congratulate ourselves austerely for having settled, like adults or Europeans, upon a course of prolonged but tolerable hopelessness" -- as a covert swipe at the Partisan Review crowd with their "European" tastes in Marxism and literature. In The American Adam, after all, Lewis acknowledged Matthiessen as "a wise and dedicated teacher and an unforgettable friend" (iii), and these were the critics who had attacked that friend so harshly in the year of his suicide.[4]

Lewis's debt to Matthiessen is obvious from the first page of his chapter on Melville. The title ("The Apotheosis of Adam") and the epigraph, taken from a variant version of "Billy in the Darbies" ("I bless his story, / The Good Being hung and gone to glory") signal how important Billy Budd will be to his own interpretation of Melville's oeuvre. He, too, sees the posthumous novel as the fulfillment of Moby-Dick. The measure of the American artist's greatness, according to Lewis, is how acutely he feels the loss of /pp. 14-15/ optimism and innocence. For Melville that loss was "the supreme challenge to understanding and to art," and over the course of his literary career, he came to terms with it, "terms of extraordinary creative tension in Moby-Dick and terms of luminous resolution in Billy Budd" (130). Like Hawthorne, Melville made "a spiritual journey from sunlight through the fires of hell to a final serenity" (134). Moby-Dick represents the antithesis in this schema, the "fires of hell" counterpoint to the innocence of Typee. Lewis calls it an angry book, but Melville is able to "hold his anger in balance" (138). The dialectical form of Moby-Dick, as Lewis describes it, is remarkably similar to Chase's romance -- "an elaborate pattern of countercommentaries ... a novel of tension without resolution." Lewis, however, sees the novel as a stage in the development of "a more durable innocence" (146). 
In 1948, around the same time that Chase submitted the manuscript of his Herman Melville to Macmillan, Trilling was working hard to secure his protégé an appointment at Columbia in the English Department. Since Trilling assumed that he himself would shortly be taking on the responsibility for teaching Victorian literature, he was eager to find a congenial colleague with whom he could share the nineteenth-century, American and British. Trilling feared that middlebrow faculty members like Joseph Wood Krutch and Mark Van Doren would find Chase's book on Melville "too Freudian, etc. and do in the whole business" (letters to Chase, 11 Feb. 1948; 15 Nov. 1948), but as it turned out, Van Doren presented no obstacle. He liked the book, even though he was puzzled as to what Chase meant by the liberal. "... I thought it best not to explain," Trilling remarked parenthetically in a letter to Chase. "I only smiled" (6 Dec. 1948).

Herman Melville (1949) represents Chase's full-scale attack on thirties' liberalism and his attempt to construct a "usable past" in Cold War, modernist terms:

If our new liberalism of the 1940's -- of which in political theory Mr. Arthur Schlesinger, Jr., is the most brilliant spokesman -- is to merit its assertion of superiority over the bankrupt liberalism of the thirties, it must establish itself in the best tradition of the American Past. The search of the older liberalism for "social realism" led it to a most culpable underestimation of Hawthorne, Melville, and James. (209)

Chase posits a meta-narrative of personal and national coming-of-age in the Melville canon that involves three figures: Ishmael the outcast son, who in seeking his paternity and identity, encounters a true or false version of a redemptive Prometheus. The "true Prometheus," although never fully realized, is partially limned by recurring portraits of the "Handsome Sailor," men like Marnoo, Jack Chase, Ethan Allen, and Bulkington -- but not Billy Budd. Nearly identical to Daniel Bell's "twice-born intellectual," the true Prometheus tempers revolutionary energy with a tragic awareness of human limitation; "He is Prometheus, as we may say, in a state of becoming Oedipus" (3-4). As for the "false Prometheus," there are actually two versions. One, represented by John Paul Jones and Ahab, is the moral extremist incapable of recognizing life's ambiguities, the monomaniacal leader whose messianic quest destroys himself and his followers. The other false Prometheus -- Ben Franklin, Plinlimmon, the Confidence Man -- is bland, glib, and disingenuous. Chase quotes with approval the Missouri bachelor's accusation in The Confidence Man that this elusive, eponymous 
figure is "the inveterate understrapper of the wicked man. You may be used for wrong, but you are useless for right." "Surely," Chase continues, drawing a parallel between the Confidence Man and the fellow traveler, "these words strike home to anyone who has watched the modern American liberal movement break down and surrender its responsibility because so many of its proponents have become 'understrappers' to Soviet foreign policy and the American Communist Party" (207). If the Confidence Man as false Prometheus corresponds to the Popular-Front liberal, the other false Prometheus, in all his single-minded fury and apocalyptic grandeur, resembles the Third Period Communist. The true Prometheus, of course, is the anti-Communist liberal. What Chase has done in this study is to recast the Melvillian canon in terms of the Cold War "crisis" in liberalism: Ishmael/ America may disastrously choose either of his false fathers on the political left, Ahab/Stalin or the Confidence Man/Henry Wallace; on the other hand, he may be wise enough to embrace his true father, the Handsome Sailor, who bears a striking resemblance to Arthur Schlesinger, Jr., sans bowtie and glasses.

Chase implies that the New York Intellectuals were in a unique position to appreciate Melville. The progressive, "Christian" school represented by Matthiessen was blind to the fact that Melville was a critic of progressive liberalism, while the New Critics, "who have not subscribed to the progressive doctrines," have largely ignored him (ix). Matthiessen is cited only twice in the index, but Chase's study is clearly a rebuttal to Matthiessen's interpretation of Melville in American Renaissance. In order to deflate what he takes to be the piety and solemnity of Matthiessen's religious approach, Chase turned, ironically enough, to another progressive Americanist, Constance Roarke, and approached Moby-Dick as a comedy rather than a tragedy. "Melville, we must remember, was a humorous writer, as well as a lyric and epic writer" (67). Drawing on the folkloric and popular traditions that Roarke had mined in American Humor and Trumpets of Jubilee, Chase discovers a cultural kinship between the commercial spectacles of P. T. Barnum and Moby-Dick. The former were colossal hoaxes, dressed up in pseudo-scientific and didactic trappings, pulled on a cooperating public; similarly, Moby-Dick was a "literary-scientific extravaganza" (77), a whale hunt in the tradition of the tall tale. Its narrator, Ishmael, was a highbrow relative to Sam Slick, the Yankee peddler (69), but he was also a blank mask, "elusive and impersonal," like the typical yarn spinner. Ahab, too, is something of a two-dimensional comic figure since his overweening boasting and colossal rage have affinities to the "screamer" and "ring-tailed roarer" (96-97).

Despite his reliance on Roarke, Chase is hardly a populist in his approach to Melville. In fact, the point of his foray into popular culture is to confirm Melville's highbrow credentials. "Barnum's use of the peculiarly American amalgam of fact and fantasy," according to Chase, 
served in effect to affirm that the high and difficult emotions of wonder and exaltation did not really exist or did not need to be taken seriously ... The commercial classes were willing to be the most abject kind of dupe if only they were given in return the comfortable sense of having mastered and destroyed every high or fierce emotion. (81)

Chase's attitude toward popular culture is not far removed from that of the Frankfurt School or Clement Greenberg and Dwight Macdonald. Barnum is successful because he flatters his audience and confirms their selfcomplacency. Moby-Dick, on the other hand, is a hoax that must be taken seriously; it "is directed against those who are looking for a hoax" (82).

For Chase as for Matthiessen, Ahab (who is obviously more than a ringtailed roarer) is really the focus of his analysis of Moby-Dick. Although Ahab is not without his virtues, over the course of the narrative he ultimately becomes the false Prometheus. In him, "Promethean élan ... become[s] mechanical" and "degenerate[s] into force" (46). Cobbled together by the ship's carpenter and blacksmith, Ahab is more machine than human being. When Chase quotes the captain's grimly playful commands to the blacksmith for a made-to-order man with no heart, a brass forehead, and steel shoulder blades (48), he evokes for a postwar audience Stalin, the man of steel, or Schlesinger's totalitarian functionaries: "the tight-lipped, unfeeling, uncommunicative men, as if badly carved from wood, without humor, without tenderness, without spontaneity, without nerves" (Vital Center 57). The dehumanized captain, moreover, orchestrates the "machinery of dictatorship" (55) as the enlightened leader becomes a "sultan." No longer the foe of the "divine Tyrant," as the true Prometheus is, he now "must play the game of the Tyrant" (54). The tragedy of Moby-Dick, says Chase, who isn't particularly interested in tragedy in formal terms, is the failure of leadership. Ahab is not a pragmatic, consensus-building centrist but a charismatic dictator. The mass man of the Frankfurt scholars refused to challenge and thereby internalize patriarchal authority; he chose instead to defer to the omnipotent leadership of Hitler or Stalin. So too, Ahab "can love only that abstract father ... those images of the father which represent pure power ... set free from the fallible responsibilities of human morals and emotions" (62-63). Moby-Dick embodies for Ahab this abstract ideal. According to Chase, the white whale does not represent evil, as Matthiessen's conventional reading of the novel asserts, but rather "purity, the purity of an inviolable spiritual rectitude ..." (62) The white whale, in other words, is the Red menace. Like the Soviet totalitarian state, society aboard the Pequod "can be only an anarchy planned in the likeness of a machine ... driven forward ... to self-destruction in the name of purity" (63). The sane alternative, of course, is heroically to accept "the fallible responsibilities" of existential man, as the anti-Stalinist liberals have. 
In Moby Dick and the Cold War, Donald E. Pease argues that Matthiessen inaugurated, unwittingly, the Cold War reading of Moby-Dick as the triumph of Ishmael's freedom over Ahab's totalitarian will. Certainly the "premature counter-Progressivism" (as the State Department might have called it) of American Renaissance insured its continuing authority in the postwar period. But Chase's interpretation of Melville reveals an equally compelling need for the repression of the Matthiessenian reading due to its progressiveliberal inscriptions. Like other Americanists of the forties, Matthiessen had legitimated Melville by reference to classic authors, notably Shakespeare and the metaphysical poets. His affirmative tragedy (along with Lewis's tragic optimism) was both political and spiritual, wedding the utopianism of the Popular Front with Christian redemption. Chase, on the other hand, was skeptical about faith, in man or God, a position consistent with the postwar "failure of nerve" rhetoric, and his attentiveness to the comic and "low" origins of Moby-Dick expresses an impatience with the pieties of old liberalism. Both Matthiessen and Chase recognized heroic qualities in Ahab, but for Matthiessen the aging captain symbolized the dangers of Emersonian individualism, entrepreneurial capitalism, and spiritual isolation. To Chase, however, Ahab represented both versions of the false Prometheus; Stalin and "Stalinist," the captain was both a totalitarian despot and an evacuated mass man willing to sacrifice his individuality for an abstraction, to "disappear into the whiteness of the whale" (62).

Matthiessen and Lewis regarded the novels Melville wrote between MobyDick and Billy Budd as failures; Chase, on the other hand, found reason to value Melville's satire on American optimism, The Confidence Man, in no small part because it provided a handy stick with which to beat the progressive American Studies critics. "If some inscrutable fate should condemn all but two of Melville's books to oblivion, he says, "we should want to save Moby-Dick and The Confidence Man ... [which] are Melville's two preeminent moral statements" (293). That Matthiessen and Lewis would have salvaged Billy Budd instead is a political as well as an aesthetic judgment.

Being the most Progressive of all counter-Progressives hardly situates the American Studies critics as radical leftists, nor, obviously, does Chase's antiStalinism approach the right-wing excesses of McCarthyism; nevertheless, the political tensions between old- and new-liberal readings of Moby-Dick qualify assumptions about the consensus of consensus criticism.

Matthiessen and Chase were responsible for two of the most influential paradigms of the formative period of modern American Studies, and it is reasonable to assume that Chase's theory of American romance was heir to Matthiessen's American Renaissance. Yet the younger scholar's revisionist reading of Moby-Dick in the early days of the Cold War, which turned Ahab into a cautionary figure of Communism rather than capitalism, suggests that politically American romance was not indebted to American Renaissance but rather an alternative to it. 


\section{Geraldine Murphy \\ Department of English \\ City College, CUNY}

Surface Page d'Acceuil/Home Page

\section{Works Cited}

Arac, Jonathan. "F. O. Matthiessen: Authorizing an American Renaissance." In Michaels and Pease, 1985: 90-112.

Cain, William E. F. O. Matthiessen and the Politics of Literary Criticism. Madison, WI: U of Wisconsin P, 1988.

Chase, Richard. Herman Melville: A Critical Study. NY: Macmillan, 1949.

Cowley, Malcolm. The Literary Situation. 1954. NY: Viking, 1958.

Fiedler, Leslie A. "American Literature." Contemporary Literary Scholarship: A Critical Review. Ed. Lewis Leary. NY: Appleton-Crofts, 1958: 157-85. . Being Busted. NY: Stein \& Day, 1969.

Gunn, Giles B. F. O. Matthiessen: The Critical Achievement. Seattle: U of Washington P, 1975.

Howe, Irving. "The Sentimental Fellow-Traveling of F. O. Matthiessen." Partisan Review 15 (1948): 1125-29.

Lewis, R. W. B. The American Adam: Innocence, Tragedy, and Tradition in the Nineteenth Century. U of Chicago P, 1955.

Matthiessen, F. O. American Renaissance: Art and Expression in the Age of Emerson and Whitman. 1941. NY: Oxford UP, 1968.

. From the Heart of Europe. NY: Oxford UP, 1948.

Michaels, Walter Benn and Donald E. Pease, eds. The American Renaissance Reconsidered. Baltimore: Johns Hopkins UP, 1985.

Parker, Hershel. Reading Billy Budd. Evanston, IL: Northwestern UP, 1990.

Pease, Donald E. "Moby Dick and the Cold War." In Michaels and Pease (1985): 113-55.

Stern, Frederick C. F. O. Matthiessen: Christian Socialist as Critic. Chapel Hill: U of North Carolina P, 1981. 
Trilling, Lionel. Letters to Richard Chase. Richard Chase Papers. Columbia University, NY.

Wise, Gene. American Historical Explanations: A Strategy for Grounded Inquiry. Homewood, IL: Dorsey P, 1973.

[1]This paragraph is taken, nearly verbatim, from a previously published article, "The Politics of Reading Billy Budd," American Literary History 1 (1989): 361-82. My analysis of progressive and anti-Stalinist readings of Moby-Dick is a companion piece to the earlier essay, both of which comprise a chapter in a forthcoming study of anti-Stalinist poetics.

[2]As Cain points out, the publication of From the Heart of Europe coincided with the Communist take-over of Czechoslovakia, making the hearty solidarity Matthiessen describes in his memoirs seem "pathetically foolish and misguided" (111).

[3]In "F. O. Matthiessen: Authorizing an American Renaissance," Jonathan Arac observes that the composition of Matthiessen's classic coincided with the Popular Front, a time when "radicalism meant reconciliation." "The Popular Front enabled Matthiessen's criticism, his politics, and his religion to interact powerfully and positively,"(100) he argues.

[4]It must be noted that Lewis thanked one New York Intellectual -- Alfred Kazin -- in his preface as well. In American Fiction in the Cold War, Thomas Hill Schaub makes essentially the same point I do when he says that Lewis's relationship to the new liberalism was "less direct or sympathetic" than that of Chase, and he goes on to point out that the immediate political context is lost to most contemporary readers $(23,24)$. Schaub doesn't, however, address the progressive origins of Lewis's strictures. 